\title{
9. Interdisciplinarity, Archaeology and the Study of Medieval Childhood
}

\author{
Carenza Lewis
}

Children's lives are important, both in their own right because childhood is a universally experienced stage of life, and because the perception and treatment of children both reflects and impacts on society more widely. However, children's lives are elusive to the archaeologist, as children leave less physical trace than adults in the material record (e.g. Lillehammer 1989; Chamberlain 1997, 249). In order to find archaeological evidence for childhood we need to know what it looks like; but in order to know what it looks like, we need to find it: the ultimate taphonomic conundrum. In attempting to resolve this, it is clear that we should consider the contribution other sources of evidence can make. This chapter explores analyses pertaining to medieval children carried out within four non-archaeological disciplines - History; Art History; Literature; and Folklore Studies in the hope that it may inspire and encourage greater interdisciplinary familiarity and exploration. ${ }^{1}$ Considering approaches from these disciplines is not intended to suggest that there are (or should be) rigid distinctions separating material of interest to different disciplines: this is simply not the case - an illustrated parchment account of a medieval saint's life, for example, is simultaneously text, art and artefact. But different disciplines do use different techniques and approaches, and so the aim in this chapter is to look at the potential that different analytical approaches have to illuminate and expand our knowledge and understanding of medieval children and childhood, and how this can complement archaeological approaches. We will also see that the prevailing theoretical framework within which research is conducted is crucial to the capacity of scholars, in any discipline, to engage with the evidence for childhood.

\footnotetext{
${ }^{1}$ These disciplines inevitably touch on material from other disciplines such as Philosophy, Theology and Historical Geography which will not be discussed separately for reasons of space. These are of course not the only disciplines from which archaeologists of medieval childhood can potentially learn: Social Anthropology, Sociology, Psychology, Education and Social Geography have all contributed useful information and ideas while Medicine, Pathology, Forensics, Physics, Chemistry and Biology provide many invaluable investigative techniques. But these disciplines are not generally concerned with medieval material as such, so will not be included here.
} 


\section{History}

History is defined here as knowledge of the past constructed through (purportedly) factual written texts. Historical sources for the medieval period include a wide range of texts mostly created for the purposes of observation, administration and/or instruction, such as chronicles, letters, financial and legal records and medical texts. History is perhaps the most obvious discipline to consider in this chapter, as written sources can record people's personal experiences and attitudes in ways that no other source can. Medieval textual records are partial in what they record, but of equal significance to realising the potential of written sources for illuminating the lives of medieval children have been the attitudes of historians.

Significant changes can be discerned in the practice of historical research over the last 150 years. As E. H. Carr $(1961,3)$ commented, by the nineteenth century, the optimistic belief of 'clear-eyed self-confident' British historians was that texts could be used to reconstruct narrative accounts of the past tracing sequential chains of cause and effect using an empiricist positivist approach, in which the historian should 'first ascertain the facts, then draw your conclusions from them' (Carr 1961, 5). Thus, the historian would be able 'simply to show how it really was' (Carr 1961, 5), ideals epitomised in the 'national narratives and admiring biographies' of historians such as George Trevelyan, the 'Grand Old Man of British History' (Cannadine 2002, viii). But by the 1950s this imperious confidence had been replaced by a 'distracted scepticism' (Carr 1961, 5), which recognised that historical 'facts' are rarely simply factual and that historical explanations are not final or immutable, but profoundly mutable, influenced by the time and circumstances within which the historian is working. Under the influence of social science, scholars such as Carr (1961) in his influential What is History? urged historians to focus on understanding long-term economic and social processes, rather than the roles of individual events or people. The so-called 'New History' dominated historical scholarship in the 1970s and 1980s, dividing the discipline between advocates of Carr and those who preferred more traditional approaches (e.g. Elton 1967). When David Cannadine revisited Carr's 'What is History?' question in 2002, the contents page alone showed how History as a discipline had developed, with chapters on Social History, Political History, Religious History, Cultural History, Gender History, Intellectual History and Imperial History, each written by different authors (Cannadine 2002). History now is broader but also more specialised with 'a more modest, more realistic and thus more helpful agenda - not the history of society as a whole, but the history of various aspects of society' (Cannadine 2002, x).

Reading this, we might reasonably hope that children would loom large in recent historical research. Certainly, children are of more interest to post-modern historians interested in minorities and focussed on multi-vocal narratives and on understanding the past rather than explaining it. Indeed, as Carr penned his final words, Philippe Ariès' (1960) seminal publication broke the silence surrounding children in the past: although seriously flawed and much-criticised, he deserves credit for opening up the subject. Since then there has been a blizzard of historical research on children (deMause 1974; Stone 1977; MacFarlane 1985; Hanawalt 1986; Shahar 1990; Postman 1995; Jenks 1996; Heywood 2001; Orme 2003; Cunningham 2005; Rosenthal 2007). Much early interest focussed on ways in which information about children could advance understanding 
of other subjects, such as Gender History (e.g. Labarge 1986; Bennett 1987; Goldberg 1992; Leyser 1995), Medical History (e.g. Porter 1997; Rawcliffe 1995) and Family History (Hanawalt 1986; 1993). Now, however, there is growing interest in children's lives for their own sake. By 2007, Margaret King was able to summarise the achievements of the previous forty years of research into the early modern period as follows:

historians have uncovered the traces of attitudes toward children - were they neglected, exploited, abused, cherished? - and patterns of child-rearing. They have explored such issues, among others, as the varieties of European household structure; definitions of the stages of life; childbirth, wetnursing, and the role of the midwife; child abandonment and the foundling home; infanticide and its prosecution; apprenticeship, servitude, and fostering; the evolution of schooling; the consequences of religious diversification; and the impact of gender

King 2007, 371

However, despite some notable publications (e.g. Shahar 1990; Orme 2003), the medieval period has been given less attention, with interest focussed mainly on medical and didactic sources, where children are most visible (e.g. Orme 1973; 1989). Part of the reason for this neglect is that the conventional sources for a history of medieval childhood have little material of obvious use. The narratives of contemporary chroniclers, for example, form the backbone of our understanding of the political history of the medieval period and provide the closest equivalent we have to individual biographies. Many medieval writers knew the people they wrote about well enough to record intimate details, such as William of Malmesbury (c. 1095-1143), who records, for example, that Henry I was a heavy sleeper with a tendency to snore (Giles 1847, 446-7) - but they tell us hardly anything about his childhood. On this period of life, the medieval chroniclers are mostly frustratingly silent.

Legal and administrative sources have - perhaps unexpectedly - proved more fruitful, as Barbara Hanawalt (1986; 1993) has demonstrated, meticulously combing through thousands of coroners' records to explore medieval family life. These legal accounts of incidents, accidents and injuries encompass a much wider spectrum of society than the chroniclers, providing vivid glimpses of the everyday lives of ordinary people, including children:

Agnes ... was tagging along with other children and playing in the king's highway. She tried to follow the others across a stream and drowned ... A girl of two and a half came out of her father's house with a piece of bread in her hand when a small pig came up and tried to take it from her, pushing her into a ditch

Hanawalt 1986, 180

A little girl of four was holding a duck in her hands and wanted to put it in the river ... Wiliam Annotson, four and half years old, went to a well and saw his face reflected in its water. When he tried to reach down and touch the face, he fell in 
These children only appear because they died an unnatural or suspicious death (Hanawalt 1986, 272), but, nonetheless, coroners' records provide illuminating glimpses of the lives of medieval children. Although they do not generally record emotional responses from parents faced with the accidental death of a child, this does not, of course, mean that these were not forthcoming, simply that they were not relevant to the coroner's task of ascertaining the circumstances surrounding the incident. Indeed, some accounts demonstrate the lengths parents would go to in attempting to save an endangered child, as in the case of Alice Trivaler who returned to her burning house to rescue her son: 'Alice remembered her son was in the fire within, she leapt back into the shop to seek him, and immediately when she entered she was overcome by the greatness of the fire and choked' (Hanawalt 1986, 184-5).

By meticulously compiling and aggregating snippets of information about children, valuable clues about the perception and experience of medieval children and childhood can emerge. William MacLehose (2006) has recently applied this approach to a range of twelfth- and thirteenth-century texts including medical treatises, religious writings and chronicles, in order to elucidate medieval attitudes to different stages of childhood. This has produced a 'subtle and scholarly study of high medieval discourses on childhood', which provides nuanced and compelling evidence that '[i]n the Western Christian society of the central Middle Ages, the child as a cultural category most certainly existed' (Phillips 2008, 1216). MacLehose has identified a growing anxiety in the twelfth and thirteenth centuries regarding the vulnerability of children, citing Eckbert of Schönau (c. 1120-84), who suggested that half of children born did not live to adulthood, as one example of a writer who was 'was preoccupied with the death of infants' (MacLehose 2006, ch. 2, 32). This, MacLehose argues, reflects a pervasive anxiety in the twelfth century over the physical safety of children, shown also in contemporary theological debates about their post-mortem fate, especially of those who died in early childhood (MacLehose 2006, ch. 2, 32-5), before they were old enough to understand Christian teaching. Debate raged as to whether such children were inherently good (because they were incapable of knowing enough to be deliberately evil) or inherently bad (tainted by original sin and the sin their parents committed during their conception). Such debates reveal much about contemporary notions of cognitive development in children, as they often hinged on the age at which children could understand the commitment involved in being baptised into the Christian faith. MacLehose (2006, ch. 2, 33) contrasts neoPelagian heretics who 'argued that children were sinless and therefore were already counted among the saved' with orthodox writers such as Peter the Venerable who were forced into 'defending the existence of original sin and ... to articulate a negative assessment of the moral world of children' (MacLehose 2006, ch. 2, 33). For the latter, 'childhood appeared to be morally lacking ... the child could not understand faith, choose the right path, or actively approach baptism, but he needed all of these things for salvation because his soul was unclean' (MacLehose 2006, ch. 2, 33). Polemicist theologians responded to these interpretations using the Bible 'to show that children had a close connection with piety and purity, and the citation of biblical passages by polemicists of the twelfth and thirteenth centuries could reveal the metaphoric value that their contemporaries placed on children' (MacLehose 2006, ch. 2, 64).

MacLehose also analyses contemporary writers' accounts of children whose murder gave rise to religious cults, such as William of Norwich (d. 1144) and Hugh of Lincoln 
(d. 1255). MacLehose (2006, ch. 3, 4) shows that in such circumstances the child could be represented variously as 'a catalyst, a passive object of hatred by the Jews, the object of sadness on the part of the mother, and the object of pathos felt by the Christian crowd' and/or as a symbol of 'sanctity, of simple piety, of innocence, of sacrifice, of human frailty and loss, of an ignorance that unwittingly reveals truth' who could also show 'a carefree playfulness and naïveté'. These perspectives reveal contemporary attitudes pertaining to children and childhood, at a time of growing interest in the cult of the Virgin Mary, idolised as a mother who both nurtured and grieved for her child. These sources connected Mary's specifically maternal functions 'with an increased emotional awareness of, and concern for, the Child and any child'. A change in the role of such tales occurs mid-thirteenth century, when the cult of Hugh of Lincoln extended beyond the merely local (unlike most previous child victims), ultimately receiving English royal approval and leading to the arrest of ninety-three Jews, nineteen of whom were executed (MacLehose 2006, ch. 3, 20). Although Hugh of Lincoln's story was clearly used as propaganda against a group the crown wished to persecute, it is significant that it was the murder of a child that was used to fuel popular outrage against English Jews and fatally undermine support for them (see also Hall this volume). Historical analysis, therefore, has the potential, given assiduous persistence and painstaking attention to detail, to reveal not only aspects of the lived experience of medieval childhood, but also, in reading beyond the literal words, to provide new perspectives on contemporary notions of childhood and the ways these could be used to achieve wider social and political aims.

\section{Art History}

Art History is the study of the production, techniques, form and role of art in the past, today a wide-ranging discipline with a historico-sociological focus encompassing the role of art in society. ${ }^{2}$ Works of art often feature in publications by medievalists (albeit often simply as illustrations), and studies of childhood are no exception. ${ }^{3}$ This is despite a commonly held belief that children are rarely represented in medieval art, and then only as miniature adults - an assertion indeed used by Philippe Ariès $(1960 ; 1962)$ to support his view that there was no notion in the medieval period of childhood as a distinct stage in life. Few would now agree with Ariès, and contextualised analyses of the depiction and presentation of children in the art of the medieval period can, as we shall see, be illuminating.

The very term 'art' of course immediately raises the oft-asked question 'what is art?' (e.g. Tolstoy 1995; Gombrich 1950; Pooke and Whitham 2010, 1-25). An object regarded as 'Art' today may not have been perceived as such when it was first made, nor was the person who made it necessarily regarded as an 'artist'. ${ }^{4}$ The medieval period was

\footnotetext{
2 The mission statement of the Journal of Art Historiography states that '[c]onsequent to the expansion of universities, museums and galleries, has evolved to include areas outside of its traditional boundaries' (available at http://arthistoriography.wordpress.com/mission-statement (accessed January 18th 2013)).

${ }^{3}$ See for example the paperback editions of Orme 2001 and Heywood 2001, both of which include part of Bruegel's painting of 1560 Children's Games on the front cover.

${ }^{4}$ This definition is offered by http://www.arthistory.sbc.edu/artartists/artartists.html accessed 18th Jan 2013.
} 
'saturated with images' (Aston 2003, 68), as a range of artistic media were widely used to convey messages that were both explicit and implicit to a largely illiterate population. These included drawing, painting (of walls and windows as well as notionally portable pieces such as altarpieces), engraving, sculpture, ceramics, jewellery and numerous other decorated artefacts such as reliquaries as well as aspects of architecture. Such art is, of course, always artifice: medieval images were constructed and manipulated to accord with convention and to convey meaning. The pages and margins of devotional books, for example, such as the Luttrell Psalter (Brown 2006) or the Book of Hours of Mary of Burgundy (Miller 1995) include images showing aspects of contemporary life, but such images are complex, and the motivations behind them need to be elicited in order to understand medieval society.

One of the classic art historical sources for information about late medieval/early modern children's play is Pieter Bruegel's Children's Games, painted in 1560. This depicts a large number of children playing a wide range of different games, and the level of detail provided can be enticing to the medievalist wishing to know more about the culture of childhood. This, of course, is not an exact representation of a real scene, but a carefully composed and constructed image liable to be misinterpreted if the factors determining the selection and presentation of the images are not understood. This was highlighted more than thirty years ago by Sandra Hindman (1981), before which date Children's Games had been interpreted either as a simple visual encyclopaedia of games, or as a more complex allegory (about which opinions varied widely: see Hindman 1981, 448 for relevant bibliography). Hindman analysed the visual structuring of the images, including the placement of the children engaged in different activities relative to each other and to the painting as a whole, as well as the use of colour and images as metaphors, such as masks, symbolising deceit, and an owl, symbolising wisdom, about to be shot by a boy with a pop-gun. Hindman also examined the artistic precedents for Children's Games and related artistic traditions in which games and children figure prominently, suggesting that Bruegel's painting represents, in fact, a transformation in the meaning conveyed by images of children (Hindman 1981, 449) from that of innocence to that of folly.

Hindman's discussion of how this allegorical message was structured makes some observations salient to the scholar of late medieval children. Firstly, she firmly dismisses the idea that Bruegel's children are actually miniature adults. She shows them to be wearing garments typical of sixteenth-century northern European children, and engaged in play activities genuinely associated with children of this date (Hindman 1981, 448-9). This was essential for the allegorical message of the painting to work:

Whatever other meanings it now evokes, Children's Games still represents real children playing actual games in front of a believable town hall, a fact that also contributed to the way it was perceived ... The interpretation of Children's Games ... argues for an artist who was intent on depicting the everyday reality of peasant children, while at the same time eliciting verbal allusions, the recognition of which would enhance the richness of the painting 
Hindman's $(1981,449)$ overall conclusion, that 'Bruegel transformed earlier traditions in which games represented the months or the Ages of Man ... [into one in which] children's games [are used] to present the folly of man as a characteristic of adolescence and manhood, as well as of youth and infancy', provides an interesting new perspective on changing contemporary notions of childhood. According to Hindman, Bruegel is conveying (and perhaps even propagating) new northern European adult attitudes to childhood, which were changing from a late medieval notion that childhood represented innocence and even the pre-lapsarian golden age of humanity, to one where childhood is a metaphor for credulous foolishness. This contrasts with views (commonplace and conventional even in those who reject Ariès' thesis) that it was only later - during the Renaissance and the Enlightenment - that adult (and especially parental) attitudes to children became more indulgent, nurturing and engaged, and a culture of childhood developed for the first time (King 2007, 371).

In another art historical discussion, more recently Sophie Oosterwijk $(2008,00)$ has argued that rather than ignoring children 'medieval artists actually showed a predilection for depicting the births of all kinds of "historical" figures', including the Virgin. Oosterwijk $(2008,00)$ also notes that the theme of The Ages of Man, frequently depicted in medieval art, always includes a childhood stage, while in more extensive versions childhood is even sub-divided into different stages as infants are usually shown as swaddled babies, and toddlers try out their first steps in a childwalker while older children play with toys or carry schoolbooks'. Oosterwijk $(2008,00)$ cites the popularity of the story of the Massacre of the Holy Innocents in medieval art as suggesting that 'medieval people viewed child death with anything but indifference' and goes on to say that the medieval popularity of the image of the Virgin Mary and infant Jesus 'could only have worked if people recognized its fundamental truth: the bond of affection between mother and child' (Oosterwijk 2008, 00).

Oosterwijk has also refuted Ariès' assertion that the absence of tomb effigies for medieval children signifies parental indifference, pointing out that 'although costly burials and monuments were affordable only to the wealthy few, some royal and aristocratic parents seem to have spared no expense in the funerals of their deceased children, who might subsequently be commemorated by costly monuments' (Oosterwijk 2008, 00). One example is Katherine, the disabled daughter of Henry III and Eleanor of Provence, described by Matthew Paris as 'speechless and helpless' who died in 1257 aged just three years (Badham and Oosterwijk 2012,187-93). While acknowledging that one function of the effort, innovation and cost expended on the design and execution of Katherine's monument was to advertise the status of her parents, Badham and Oosterwijk point out that this was a much-mourned death, referring to Matthew Paris' contemporary records of the grief of the queen who 'as a result of her anguish was seized of a grievous illness that neither physician nor human consolation could alleviate' and John of Oxnead's accounts that the king 'was plunged into such sorrow that he fell ill' (Badham and Oosterwijk 2012, 171; see also Hall this volume).

Oosterwijk gives further consideration to why, on the rare occasions that children appear on medieval funerary monuments, they are typically depicted as adults, which has given rise to the belief that children were regarded in life as 'miniature adults', a notion she rejects (Oosterwijk 2010, 47). For example, the tomb chest of Edward III (d. 1377) depicts his son William of Windsor (who died shortly after birth in 1348) as a 
'weeper' - or mourner - of near-adult size and stature. William shares his own tomb in Westminster Abbey with his sister Blanche of the Tower who also died as a baby (in 1342), and both are depicted in effigy as much older children or young adults: 'William is shown in a short tunic and tight hose, Blanche is presented as an elegant female with her hair tied up in fashionable cauls on either side of her face' (Oosterwijk 2010, 53-4). In York Minster, William of Hatfield (another son of Edward III who died in infancy in 1337) is depicted in effigy as 'an elegantly dressed young prince' (Oosterwijk 2010, 54-5). Oosterwijk contends that such effigies are not evidence of a fourteenth-century perception of children simply as adults-in-waiting devoid of their own childish identity and culture, but rather they 'reflect medieval theological thinking about the perfect age of Christ that the blessed would attain in heaven'. That is, the children are shown on monuments as the young adults they would become in heaven, not as the children they had been at death (Oosterwijk 2010, 55-7).

Oosterwijk $(2010,59)$ concludes that while inclusion of children on funerary monuments is not proof of affection, their absence does not preclude it, and 'it would be wrong to assume that children were neither loved nor remembered. Even the anonymous rows of offspring on [their parents'] monuments suggest that every child counted'. She maintains that the stylised depiction of children, or indeed their apparent absence, is because artists 'had to invent ways of presenting children on tombs in line with patrons' expectations, artistic conventions and religious thinking of the period, resulting in a variety of depictions that are not always immediately recognisable as children to a modern viewer' (Oosterwijk 2010, 59).

The art-historical analyses considered above show how such studies can inform our understanding of childhood, and contemporary perceptions of it, taking us beyond the immediately apparent image to the message and the social context behind the image.

\section{Medieval literature}

Medieval literature is another potential source of contemporary information about medieval childhood. Literature has the imaginatively composed artifice of art, but is transmitted through the same textual medium as history, although it is distinct from both of these disciplines. Literature is defined here as formally composed 'imaginative writing' (Eagleton 1996, 1), ${ }^{5}$ whether in the form of poetry, drama or prose: this mostly excludes writing that 'may start off life as history or philosophy and then come to be ranked as literature' (Eagleton 1996, 7). A grey area is occupied by medieval texts written as biographical accounts for domestic consumption rather than as history, about people who may even be mythical (e.g. biblical characters, heroes from the past) or are members of contemporary (mostly elite) families, the purpose of which may have been to entertain while also recording and drawing attention to family lineages. The

\footnotetext{
${ }^{5}$ Although Terry Eagleton offers this definition simply in order to reject it, it is a useful definition for this consideration of medieval material as it enables a reasonably clear distinction to be drawn between literature and other historical sources - observational, administrative and didactic texts which purport to be factual. Today, to be defined as 'literature' a work usually also needs to be judged to be of some literary merit, which is of course inevitably difficult to define objectively. However, this does not need to be an issue here, as the purpose of this paper is to consider literary scholarship and what it can tell us about medieval childhood.
} 
distinction used here is in the approach - literary rather than historical - which has been used to analyse the texts.

The early study of Middle English literature (dating to 1100-1500 AD) in the nineteenth century was focussed primarily on philological investigation of the history and development of the English language, but attention broadened to encompass wider issues of the development of the literary form after the first world war. Since the 1980s, due to the convergence of these two approaches and increased specialisation within literary studies, 'a more certain and complete picture of the period's literary culture has emerged, not just of the texts themselves, but also of the circumstances of their production, the patterns of their dissemination, and their possible readership' (Scanlon $2009,5)$. Eagleton (1996) suggests that reading a work of literature in order to find out about contemporary life is not reading it as literature, but that does not mean that it is not an effective means of advancing knowledge and understanding of medieval childhood. Indeed, as Adrienne Gavin (2012b, 3) points out 'literary depictions of children are not only influenced by views on childhood in their times ... but also reflect and reveal concerns, cultural tendencies, and areas of interest in the period of their composition', while highlighting the important caveat that even if 'inspired by real-life originals or contemporary thought, the child in literature is inarguably a construction of art' $^{\prime}$ (Gavin 2012b, 2).

Relatively little attention has yet been given to children by medieval literary scholars: "with a few recent exceptions ... literary scholars still seem prone to "the Ariès effect" and have not attended to the widespread appearance of children and childhoods in Middle English texts' (Kline 2012, 21-2). This is beginning to change (e.g. Blake 1993; Kline 2005; 2012; Rutter 2007; Chedzoy et al. 2007; Knowles 2012), but there is still a striking dearth of research compared to the attention devoted by literary scholars to post-seventeenth-century material for and about children. For example, the survey of literature for children edited by Peter Hunt (1995) included just one chapter on the entire period up to $c$. 1700, while more recently Adrienne Gavin's (2012a) edited volume on the child in British literature from the medieval period onwards includes only two papers on medieval material.

However, that literary analysis can provide new perspectives on medieval attitudes to children and childhood is apparent in some recent studies, particularly those addressing the Pearl poem, written in Middle English probably in the 1380s or 1390s (Stanbury $2001,6)$. The poem recounts the dream of a bereaved father in which he meets his dead infant daughter again as an adult woman in heaven. In his dream the father learns that his daughter's soul is not, like her body, rotting in the ground, but in heaven. He longs to join her there, but when he tries to cross the water that separates them, he wakes abruptly. Ultimately, he finds some consolation in coming to understand that only through religious observance and by going through death, can he and all humans come to the happy state his daughter is now in.

By understanding both the use of a pearl as a literary metaphor for a dead child, it becomes immensely moving:

Consumed with inconsolable grief for a lost pearl, he seems unable or unwilling to leave the place ... he stays because he believes that his pearl is still there, under the ground, tantalizingly close, yet unreachable. Any reader still unaware of the allegorical dimension of 
the pearl is likely to wonder why he does not simply reclaim his lost jewel, since he knows so precisely where it lies. The answer, of course, is that the lost pearl is not lost merely in space but in time: the child whom he remembers belongs to the past, and exhuming her body would hardly remedy his grief. His own literal-mindedness in believing that his pearl is necessarily where he left it traps him by her graveside and prevents him from imagining any other fate, either for her or for himself. Instead, the Dreamer sees the Maiden as irrecoverable, and his sense of hopelessness is underlined by his contemplation of exactly what is happening to his daughter's body

Terrell 2008, 432-3

Reading the language shows the grief of the Pearl father to be depicted as uncompromisingly visceral, deep, desperate, agonising, enduring and unbearable. The narrator is 'wounded by love beyond repair' (1. 11), his heart caught in 'chilling care' (1. 50), unmanned by 'bitter grief' (1. 51):

Are you my pearl for whom I cried,

For whom I grieved alone at night?

Much longing I for you have sighed

Since into grass you left my sight

ll 240-4

Pearl reveals much about parental attitudes to children. Sarah Stanbury $(2009,43)$ points out that the poem was 'a commissioned work, probably written as a consolatory piece to commemorate the death of a daughter'. Knowing that Pearl is not simply the grief-stricken outpourings of a fortuitously gifted literary parent (Stanbury 2009, 8) tells us something about the culture of mourning in relation to children. That such a beautifully crafted, courtly, piece of literature - elegy, eulogy, therapy and religious edification rolled into one - was commissioned about the loss of a child reveal attitudes to children's deaths in the late fourteenth century. We can infer that it was acceptable and even expected that much investment (emotional and financial) might be expended on mourning the death of a child and ultimately, in trying to achieve consolation.

Analysis of the use made of the 'pearl' as a literary metaphor also enhances our understanding of the perception of children. At its simplest level, the pearl represents the dead child: the reader, after being briefly lured into supposing it is simply a dropped gem which has 'slipped through the grass', soon realises that what the narrator seeks is, in fact, his two-year-old daughter who is buried under that grass. The pearl metaphor works at one level to show how the father valued his daughter, but also how he saw her as an innocent, pure, perfect unblemished beauty. The pearl metaphor also associates other concepts with the dead child: it 'is a gem, is a two-year old child, is a beautiful young woman, is the immortal soul, is the heavenly city - as well as a collective of the properties that inhere to each term singly' (Stanbury 2001,3). Here we see something of the ways in which young children could be perceived in later fourteenth-century England.

The pearl metaphor works at other levels as well, as Katherine Terrell points out, helping the fourteenth-century reader to understand the central message of the poem, that through religion there is hope after death, even that of a child: 
The pearl was traditionally believed to be incorruptible, and thus the description of a rotting pearl goes against all conventional wisdom - suggesting that the Dreamer is wrong either in his apprehension of his child as a pearl or in his conception of the way in which she has become 'spotte[d]' through her death and burial .... [But] applied to a human soul, sullied by sin and purified through confession, the metaphor is an apt one. The Dreamer's mistake, clearly, is in attempting to apply the pearl metaphor to the corruptible body rather than the immortal soul

Terrell 2008, 438

A further demonstration of the skill of the author, is the way the word 'spot' is used punningly to link the location of the buried child and the discolouration of physical decay: 'In its dual senses of "defilement" and "location", the repeated word echoes the Dreamer's circling thoughts, associating the physical site of the grave with the decay that takes place there and emphasizing the Dreamer's anguished obsession with the location of the grave and with the body that lies within' (Terrell 2008, 435). These metaphors are intricately woven through the poem to encourage the reader to empathise with the narrator, enhance the poem's impact and drive home its message: 'Pearl uses a dizzying punnology, embedded within concepts, words and grammatical structures and even within the system of its meter and rhyme, as if in invitation to engage with language as an encounter with haunting and repetition' (Stanbury 2001, 3-4).

The poem addresses at length the bitter, tortuous (in both senses of the word) controversy of the period: whether children too young to understand the Christian creed could or should be baptised, and, accordingly, be able get to heaven. The concept of Limbo Puerorum, which had been part of the theological canon since the mid-thirteenth century, spared unbaptised children Hell, but theologians were still in disagreement about whether children should be able to get to heaven (seen as being in the presence of God) if they had died before they were old enough to understand Christian teaching. This problem is articulated by the bereaved Pearl father who struggles to accept his transfigured daughter's explanation of the contrived rules allowing her to enter heaven when she had died before her second birthday:

You lived not two years in our land,

How to please God you never know,

Nor Creed nor prayers could understand;

ll 482-4

The daughter patiently explains to her father the compromise that allowed the Church to avoid alienating those who did not want to believe their dead children were consigned to an eternity barred from heaven.

Further analysis shows that the message of hope, the consolation the poem seeks to offer, is subtly reinforced in the structure of the poem:

Comprising twenty sets of five, the stanzas are grouped to add up to 100, a number of perfection. This symmetry is offset, however, by the curious addition of an extra stanza in the fifteenth set - with the result that the stanzas total 101. One hundred and one, a strong number that suggests new beginning after return, is doubtless no accident

Stanbury 2001, 4 
Thereby the poem enhances both its technical mastery and its impact as an allegory on divine salvation. '[O]n an individual level, Pearl describes the difficulties of the individual who we might say is "working through" grief with the aid of devotional psychology. On the collective level, Pearl offers the promise that the particular accommodation represented in the vision, the maiden one of 144,000 brides of Christ, can be available to all' (Stanbury 2001, 12).

This beautifully structured, complex, multi-layered theological message is delivered through the story of the death of a child who did not live to see her second birthday, and this again hints at late fourteenth-century attitudes to children which are tellingly different from the apparently austere, emotionless, child-denying funerary monuments. Even if the Pearl poem is a metaphor for something other than the death of a child, as some scholars have suggested ${ }^{6}$ it is still the case that, for the spiritual and/or allegorical message of the Pearl poem to work, the grief of the father would have to be recognisable and realistic to readers. He has to be not some uniquely deranged individual, but any parent, 'everyparent': 'the poem is addressing the complex work of human mourning rather than dealing exclusively in doctrinally correct consolation. The poem recognizes that the Dreamer cannot simply set aside his mourning and alter his worldview because he is told that he should; instead, he can accept the Maiden's teachings only by slow degrees' (Terrell 2008, 432).

Turning to another very different case study, James Schultz's (1995) examination of Middle High German (MHG) literature constitutes a rare example in literary scholarship of an entire volume dedicated to medieval childhood. Schultz is aware of the limitations of such material, pointing out that the texts are 'profoundly shaped by literary tradition, by the circumstances of their patronage and performance, and by a host of other factors that make it absurd to suppose they might somehow offer an accurate representation of extraliterary childhood' (Schultz 1995, 13). ${ }^{7}$ In addition, Schultz $(1995,13)$ points out that the MHG texts are restricted in their focus, with most of the children featured in the texts being idealised high-status males. The reason for this lies in their being almost exclusively written and commissioned 'by men and, less frequently, women of the nobility and the church, themselves usually of noble birth, who regarded literary patronage as a way of glorifying themselves and legitimating their power' (Schultz 1995, 13). Accordingly, Schultz $(1995,263)$ concludes that 'any attempt to read historical childhood out of literary texts must be highly problematical'.

This does not sound encouraging for present purposes, but in admitting that it would be foolish to think that they represent the real children of the German Middle Ages', Schultz $(1995,13)$ also points out that the MHG texts are, nonetheless, the best source available as 'the more usual kinds of historical sources waste hardly a word on children' (a familiar problem). More significantly, he goes on to make two important points about the value (rather than the simple necessity) of such literary sources for the study of medieval childhood, commenting that MHG texts are privileged:

\footnotetext{
${ }^{6}$ Various scholars have suggested that Pearl may be an allegory on baptism or entrance into a nunnery (Stanbury 2001, 8).

${ }^{7}$ This, of course, is true of medieval literature in other languages, including Middle English, and much other documentary evidence besides.
} 
first, because the knowledge of childhood is the culturally constructed meaning of childhood, and literary texts are a rich source of cultural meaning... Second, the representation of children in the literary texts are themselves part of the historical knowledge of childhood. They rely on that knowledge and incorporate elements of it - otherwise they would have been incomprehensible

Schultz 1995, 00

In addition, some of the statistics that emerge from Schultz's work are alone worth knowing: for example, the entire cannon of MHG texts between 1100 and 1350 refers to just 375 children, $94 \%$ of which were of noble or high birth (Schultz 1995, 59).

Analysis of these texts allows Schultz to propose a succession of distinctive phases in the literary portrayal of children in German language literature. From 1100-1150, childhood rarely features and is limited to a few religious figures, such as Jesus, Moses and John the Baptist (Schultz 1995, 200-1). From 1150-1200 a larger number of saints and martyrs appear, while secular children make a first appearance, with childhood represented as a period of preparation for adulthood (mostly knighthood) 'an age of discipline and determination, the heroic age of the knightly child' (Schultz 1995, 208). Between 1200 and 1250, descriptions of secular childhoods become more common, reflecting 'a general desire for completeness, biographical and genealogical' (Schultz 1995, 209-19). These accounts of childhood are more sentimental with children represented as loving and being loved (by parental figures and by other children) and as behaving in child-like ways such as by crying and playing with toys and pets. They are described acting naively and innocently, while in pursuit of worthy aims. This 'Golden Age of secular Childhood' (Schultz 1995, 209) in the literature does not last, with the period 1250-1300 showing a decline in interest in stories of secular childhoods, attention turning back to stories of saints, and the first appearance of negative views of childhood in the literature (Schultz 1995, 219-35): '[t]here is no child so small that he does not want to squander his time in mockery, abuse, cursing, swearing, insults, games, gluttony and all sort of loose living' (Schultz 1995, 225). This pattern continues between 1300 and 1350, when a loss of literary interest in children is shown by a $50 \%$ reduction in the number of childhood narratives, most of which Schultz $(1995,235)$ considers, in any case, to be 'derivative, cursory, fragmentary, or partial'.

Such observations are primarily socio-historical rather than literary, but Schultz also shows the potential of linguistic analysis to illuminate contemporary perceptions of children. Terms referring to babies are used very little; 'kindelin' (the diminutive of 'kint' meaning child) is not used exclusively for infants, and is in fact less commonly used for this age group than 'kint' (Schultz 1995, 23-4). The words used by MHG writers to designate children are those also used for servants or attendants, suggesting that contemporary perceptions of children were rooted in their lack of autonomy and status (Schultz 1995, 247). The use of language also reveals perceptions of gender in childhood (Schultz 1995, 21-42), as the word 'kint' is used to describe children of either biological sex from birth, but its use is differentiated by gender as children age. The word 'kint' refers to males throughout their childhood until they came of age as adults (aged fourteen to eighteen), but when used of them thereafter (which is rare) it is explicitly to signify their relative youth (Schultz 1995, 23-4). Of females, 'kint' ceases to be used at a much younger age (around seven to ten), and certainly as soon as a girl in the narrative 
has any contact with strangers/suitors. In the rare instance where ' $k i n t$ ' is used to refer to older females it is used, unlike in males, to signify their virginity (Schultz 1995, 24-5). Thus, we see that the essence of German high medieval perceptions of gendered male childhood identity lies in youth, whereas gendered female childhood identify is rooted in virginity. By implication, a boy's cultural identity as a male focusses on age, an attribute which is naturally and inevitably acquired, whereas a girl's gendered identity relied on virginity, a much more culturally nuanced characteristic and one whose retention or loss is not a natural process but one that is consciously enacted. Another telling linguistic perspective on gendered contemporary perceptions of children is the use of only one term, 'maget' (virgin/maiden) to denote female gender in children, whereas several terms are used to denote male gender (Schultz 1995, 256).

There is much more that is of interest in Schultz's research, but it is interesting to note that some of his conclusions would have been welcomed by Ariès:

Probably the German nobility of the thirteenth century did believe that children were deficient, that childhood should be focused on adulthood, that the immutable nature of the individual was revealed during childhood, that no amount of childhood dislocation could prevent the noble nature from attaining its proper place in society, that the childhood of maidens was fundamentally different from that of youths, and that childhood was more important in secular than in religious contexts

Schultz 1995, 264

Notably, while accepting that the texts are artificial constructs, not mirrors of everyday life, Schultz is clear that they do provide evidence of contemporary attitudes to children and childhood:

The MHG narratives were inevitably part of the larger cultural discourse on childhood in medieval Germany. On the one hand, they would have been meaningless to their contemporary audiences if they had not incorporated common assumptions about childhood. On the other, the textual representation of childhood must have affected the ideas about childhood, even the treatment of children, among those who were familiar with the stories

Schultz 1995, 263

These examples of literary analysis used to illuminate aspects of medieval childhood show how such work can produce nuanced perspectives which complement and extend those from other approaches. Not least, we can see how representations of children can be manipulated in order to elicit diverse responses from audiences, leaving us to wonder how such manipulation might affect what we find in the archaeological record.

\section{Folklore Studies}

Folklore can be defined as 'whatever is voluntarily and informally communicated, created or done jointly by members of a group (of any size, age, or social and educational level): it can circulate through any media (oral, written, or visual) ... The essential 
criterion is the presence of a group whose joint sense of what is right and appropriate shapes the story, performance or custom - not the rules and teachings of any official body' (Simpson and Roud 2000, v). Folklore can include traditions, beliefs, superstitions, myths, legends, songs, rhymes, pastimes, games and much else. Folklore is transmitted primarily either by verbal recounts of beliefs, traditions or stories, or by observation of or participation in activities. Written descriptions were rare until intellectual interest in the subject began to develop in the nineteenth century when many folklore collections were made, mostly by individuals with a personal interest and little or no pretension to academic status. Folklore provides a counterpoint to historical evidence (as it is not usually transmitted by being written down), to literature (as it is not usually formally composed) and to art history (as it is enacted and transmitted by participation, not by viewing). Of all of these four disciplines, folklore suffers least from being biased towards the activities and interests of the elite and the educated, and as such, despite the difficulties inherent it using it in the study of medieval childhood, it deserves serious consideration.

However, of all the disciplines considered in this chapter, folklore studies (especially those focussed on the past) present the most frustrating challenge for the scholar of medieval childhood. This is because while the potential value of evidence about 'traditions that are learned, performed and transmitted by children without the influence of adult supervision or instruction' (McCormick and White 2011, 264) is clearly immense (as there are so few other sources for this sort of evidence, which is by definition rarely written down), its reliability and temporal stability can be questionable. Here, academic folklorists admit that they suffer more than most from what Brian Sutton-Smith $(1970,4-5)$ so elegantly termed the 'triviality barrier'; that is, the reluctance of scholars in other disciplines to take their research seriously as 'English academia has almost universally turned a blind eye' (Simpson and Roud 2000, vi). This is partly because the usual robustly reflexive process of scholarly knowledge generation, which involves collecting and analysing evidence in order to develop inferences and test them against other evidence, is less easy to achieve within folklore studies. It is not alone in this, of course, but folklorists suffer from being subject to key problems inherent both in historically-based research (that direct 'live' observation, interrogation and cross-examination are not possible) and in social sciences (that the subject may not be providing an accurate, reliable, objective or complete testament).

Brian Sutton-Smith (1970, 4-6) considers those dealing with the folklore of children in particular to be particularly disadvantaged with regard to the triviality barrier. But folklorists are notable for their interest in children and their folklore, and for accepting child-related matters more readily as worthy of study in their own right (rather than an adjunct of an older or more sophisticated body of informants) than many other disciplines within the humanities and social sciences. This is another reason why archaeologists interested in medieval childhood should be critically aware of folklore studies, despite the fact that achieving temporal depth is challenging and requires folklorists to rely either on 'historic' accounts (collected when standards of scholarship were very different), or on back-projection of modern or historic accounts.

As few accounts of child-related folklore survive from the medieval period, one of the most vexed questions for medievalists when looking at folklore is, inevitably, the extent to which such back projection can elucidate the traditions of earlier centuries. Folklore 
studies started on an optimistic note in this respect, as 'early folklorists took it as read that children preserve in their games and rhymes the serious practices of previous adult generations, and were thus quick to see survivals of bride-capture, funeral customs, or foundation sacrifice' (Simpson and Roud 2000, 59). As a corollary, many early folklorists believed that there was a high degree of conservatism in children's enaction and transmission of games and traditions: Alice Gomme (1853-1938), in the introduction to her pioneering 1894 collection of children's games and rhymes, commented that '[a]lthough none of the versions of the games now collected together are in their original form ... it cannot, I think, fail to be noticed how extremely interesting these games are ... as a means of obtaining an insight into many of the customs and beliefs of our ancestors. Children do not invent, but they imitate or mimic' (Gomme 1894, x). Indeed one of Gomme's priorities in presenting her accounts of children's games was 'to deduce from the evidence thus collected suggestions as to the probable origin of the game' (Gomme 1894, ix). Although her work has been criticised in recent years (see below), in fairness to her it is extremely useful that she saw fit to include 'such references to early authorities and other facts bearing upon the subject as help to elucidate the views expressed' (Gomme 1894, ix; see also Gomme 1898). Nonetheless, amongst folklorists today the notion that children's folklore is likely to represent survival of much earlier traditions is widely doubted (Simpson and Roud 2000, 59).

Helpfully, folklorists' interest has now shifted away from attempts to use children's folklore to identify other (adult) traditions and towards exploring children's culture itself. In the mid-twentieth century, Iona and Peter Opie, the best-known twentiethcentury folklorists of childhood, published two extensive collections of games and rhymes (1959; 1969), which constitute an invaluable reservoir of knowledge about children's culture, encompassing material mediated by adults as well as that which was more child-derived and transmitted. The Opies were less concerned with eliciting earlier traditions, and focussed instead on the children's games in their own right. This is, of course, potentially a much more useful perspective for those interested in medieval childhood, although doubts remain as to what time depth children's folklore has. In 1969 the Opies (1969, 6-10) were confident that children's games, while subject to innovation and change were also prone to considerable levels of persistence over centuries. But by 1995 Brian Sutton-Smith $(1995,20)$ was less certain, emphasising that '[c]hildren's folklore is not immutable and unchanging', while, in the same volume, John McDowell applied concepts of 'mutation' and 'emergence' in exploring change in folklore and pointed out that scholars have highlighted the 'unique, unpredictable quality of any given instance of folklore transmission' (McDowell 1995, 51). No firmer conclusions have since been reached, although Charlie McCormick and Kim Kennedy White $(2011,261)$ are more optimistically prepared to assert that folk traditions can persist over centuries, including children's folklore which they suggest 'has remarkable stability over long periods of time'. The position remains largely as McMahon and Sutton-Smith $(1995,293)$ stated it: 'The field of folklore begin with an interest in origins, with survivals, and with history, and this interest will probably continue; many of the problems of historical origins and historical change have not been solved'.

McCormick and White also provide an overview of, and commentary on, current thinking in folklore studies, including that relating to children, whose folklore they view as no less valid than any other sector of society and as containing 'practically all 
of the principal genres of tradition, including games, narratives of many kinds, songs, customs, and material culture' (McCormick and White 2011, 265). Their comments reveal that the social context of enacted traditions is increasingly of interest, something recognised in Damian Webb's comments in his introduction to the 1984 edition of Gomme's opus: 'None of these sources gives specific details: what sort of children were playing the games in what sort of place and what were their ages? Were they the urban poor singing in dancing in their own back yards or were they organized groups of children playing under adult supervision?' (Webb 1984, 70). McCormick and White $(2011,265)$ echo this point, adding that 'analyzing the social interactions in which the games are embedded as at least as important as documenting the exact texts and tunes of the songs children sing or the rhymes the recite during hand-clap routines'. Their perspective on this problem reflects much current thinking within psychology and anthropology on child socialisation:

childhood traditions are an integral part of the overall enculturation process because through mastering the rules of the games or the literary structure of oral genres such as riddles and rhymes, children learn some of the fundamental aspects of cooperation and strategy that are so integral to contemporary Western society. Furthermore, much of the interaction that takes place when children play games together involves negotiation of rules and the status of various players more than the actual performance of the game itself. Many researchers believe that analyzing the social interactions in which the games are embedded as at least as important as documenting the exact texts and tunes of the songs children sing or the rhymes the recite during hand-clap routines

McCormick and White 2011, 265

Turning to one specific folklore study linked to the late medieval period, Malcolm Comeaux (2005) recalls two games, 'roly poly' and 'horse', from his childhood in the Cajun area of southwest Louisiana in the late 1940s and early 1950s. Comeaux (2005, 50-5) states that one of his aims is simply to put these on record, but he also feels that they should be 'compared with how these games were played elsewhere and at other times', and in doing so he sees similarities with some of Bruegel's images in Children's Games:

The scene of the boys playing roly poly in the Bruegel painting is an accurate depiction of the game known to the author as both roly poly and pique partout, and obvious to anyone who has ever played the game. It has, however, sometimes been misidentified as marbles or skittles. The size of the ball used by the boys in the Bruegel painting, the line of holes facing the boy about to release the ball, and the position of the boys around the holes, clearly indicate that roly poly is being played, not marbles.

In support of his identification, Comeaux cites Jeanette Hills who in 1950 identified the game by its Dutch name 'petjeball' ('hole ball') and then provides 'a good description of how to play roly poly, complete even to the point that the loser must pay a penalty'. Comeaux $(2005,63)$ goes on to say that 'The game of horse could be played in many variations, but still can be clearly recognized in the Bruegel painting. The painting of the boys playing roly poly, however, although done in 1560, could just have easily 
been painted in 1950 in South Louisiana, and without any marked changes, save for clothing styles'.

Having established to his own satisfaction that the games depicted by Bruegel are likely to have been similar to his 'roly poly' and 'horse', Comeaux comments, from personal experience, on the violent nature of both games, where children could be, and frequently were, hurt. In his experience, girls were excluded from both games, weaker or more timid boys were not allowed to play 'horse' (not out of concern for their welfare but because they might jeopardise the team which was only as strong as its weakest player) and younger boys were only allowed to play 'roly poly' if they were prepared to accept the painful consequences of loss when projectiles would be hurled at them (this is implied in one of its other names 'pique partout' (meaning 'sting everywhere')). Comeaux $(2005,63)$ goes on to suggest that the playing of these games in the sixteenth century may 'reflect a time when might made right, when issues of equality, or fairness, carried much less weight'. He suggests that the games reflect medieval society, which was 'a time of pomp and ceremony, as well as chivalry, but [it was] also a time of cruelty and early death. In life, no quarter was asked and none given, and these games mirror this attitude'. Comeaux suggests that in the medieval context horse served 'to identify the strong and the reliable, attributes critical in warfare and life in general', while roly poly "was a game whose aim was to inflict pain and punishment. Here strength and size counted for less, and what was important was the "heart" a boy had - whether or not he was willing to accept pain and punishment stoically'.

Folklore is a difficult subject for the medievalist interested in childhood, but the study outlined above is one example which shows its potential to illuminate aspects of past life which may otherwise be lost.

\section{Analysis}

There has been space to examine only a few case studies from each of the disciplines considered above, which were selected to illustrate the potential that different analytical techniques have for advancing the study of medieval childhood, and in the hope that they will inspire further exploration of reading across other disciplines. It is apparent, however, even from a cursory survey, that such potential is very high. For example, the literary and art historical studies discussed above leave one surprised that an historian writing as recently as 2007 should be able to suggest that it was not until the seventeenth or eighteenth centuries that 'obstetrical science trumped old wives' tales, the children's book industry was born - along with children's clothing, children's furniture, and children's games - and middle-class parents, publicly expressing their love for children and their grief at child death, dedicated themselves to the welfare and advancement of their offspring' (King 2007, 371). As we have glimpsed, research in History, Literature, Art History and Folklore, as well as Archaeology, have generated evidence to question, even to downright contradict, almost every one of these assertions, but this information does not seem to be penetrating as widely or as rapidly as scholars of medieval childhood might have hoped or expected. So the case for greater interdisciplinary awareness clearly still needs to be made.

Presented together, these case studies reveal what a rich perspective different 
approaches can provide, and how inferences and ideas from one discipline can support, substantiate or illuminate those from other disciplines. For example, the boys in Bruegel's Children's Games are playing a game that Comeaux's folklore study suggests to be 'roly poly', in which 'small, plucky boys were always welcome' (Comeaux 2005, 52), while dressed in clothes Hindman $(1981,449)$ identifies as those worn by younger boys aged five to eleven years. Similarly, the boys Comeaux $(2005,54)$ identifies as playing 'horse' which 'small boys would often not be permitted to play' are dressed as older boys aged over eleven (Hindman 1981, 449). Realising that Hindman's older boys are playing Comeaux's older boys' game not only supports Comeaux's linking of his games with those depicted by Bruegel, but also supports Hindman's assertion that Bruegel's depictions are accurate images of real children. Interdisciplinary study strengthens research findings by providing external data against which observations can be assessed. Hindman herself uses a knowledge of Flemish folklore to support her interpretation of the allegorical meaning of Children's Games: the Flemish proverb 'to put a blue cloak on someone' (referring to the action of an unfaithful wife) is used to identify blue as a colour associated with deceit and infidelity, used by Bruegel to link the games of blind man's buff with the marriage and baptismal processions, thereby associating marriage with folly (Hindman 1981, 451-5).

In a different vein, evidence that a culture of mourning extended to dead children, evidenced by Stanbury's and Terrell's literary analyses of the Pearl poem, supports Oosterwijk's suggestion that the apparently austere style of medieval funerary monuments for children are not evidence of any lack of emotion, but determined by social conventions in which mourning was expressed in other ways. The close dating that written documents (historical, literary or both) can provide allows us to see how short-lived some twists and turns in the representation of children are in different media in different places at different times, as Schultz has shown. Generally, it is salient to note again and again the view that representations of or about children, whether conveyed via literature, historical text or art, must be realistic in order for the originator's message to be meaningful to his or her audience.

Archaeology, a discipline which seeks to understand the past based on analysis of its physical remains, has, like the other disciplines reviewed here, come relatively late to the study of childhood (Crawford and Lewis 2008; and see also the introduction to the present volume). In the eighteenth and nineteenth centuries, interest was influenced by the classical and religious education which early antiquarians received, and relatively little attention was given to areas of study not given to advancing understanding of the civilisations of ancient Greece, Rome or the Bible. Children, of any period, were of little or no interest. In the mid-nineteenth century, publication of books such as Charles Lyell's Principles of Geology (1830-3) and Charles Darwin's On the Origin of Species (1859) attracted attention to prehistory, with the medieval period commonly dismissed as the preserve of historians and/or Gothically-inclined aesthetes. In the midtwentieth century, a processual focus on data-gathering and systemic 'longue dureé' explanations also left little space for an interest in children. More recently, however, interest has broadened, and since the late twentieth century archaeological scholarly enquiry has become more inclusive and holistic, recovery processes are ever more thorough and comprehensive, while analytical techniques are increasingly innovative, broad-ranging and finely honed. Post-modernism has led to post-processual and post- 
colonial approaches which have focussed attention on the impact of individuals and championed the cause of multi-vocality in reconstructing the lives of those whose voices have been lost. These developments should have benefited the study of childhood, and the extent to which this has, indeed, happened is reflected in a number of publications on the archaeology of childhood in the last twenty years (Moore and Scott 1997; Baxter 2005; Wileman 2005; Crawford and Shepherd 2007; Lillehammer 2010; see also the introduction to the present volume).

Nonetheless, archaeology still struggles to put children into its pictures of the past and medieval children have fared particularly badly, with the period receiving relatively little attention in publications on the archaeology of childhood (see also Crawford this volume). With a few notable exceptions (e.g. Forsyth and Egan 2005; Mays et al. 2007), childhood is only minimally present (if at all) in surveys of medieval archaeology. When thinking about the reasons why medieval archaeology is not good at putting children into its reconstructions of the past, it becomes ruefully apparent that this is not least because it is still not very good at putting people per se into the past. Excavation reports focus on the physical record of construction, deposition and disposal (a 'stones, bones, bricks and sticks'-based approach), while synthesising work commonly takes a long view in which the individual lived life, and especially that of the child, tends to get lost. Although this is beginning to change (e.g. Gilchrist 2012; and papers in the present volume), it is epitomised by reconstruction drawings of almost any medieval site, where human figures are included (if at all) in much smaller numbers than would have been present in reality. ${ }^{8}$

Greater cross-disciplinary awareness has considerable potential to advance the investigation of archaeologically-derived phenomena (Crawford and Lewis 2008). For example, MacLehose's historical analyses of medical texts, annals and theological treatises show the potential of such sources as a mine of information for osteologists, even down to details of children's development and diet, such as Aldobrandino of Siena's late thirteenth-century injunction 'that children between the ages of seven and fourteen must not drink cold water with meat, "since that could aggravate them too much"' and advice against giving children 'milk, fruit, and cheese "as much as you can", for fear of generating stone' (MacLehose 2006, 00). Palaeo-demographers exploring medieval child mortality levels and under-representation in cemetery populations will be interested to know that in the twelfth century Eckbert of Schönau commented that 'scarcely one half of [all] humans arrives alive at those days when they can know what to believe and what not' (MacLehose 2006, 00). An awareness of fourteenth-century attitudes to child death elicited by art historical and literary analysis must open the eyes of anyone working on cemetery assemblages of this date.

A small number of archaeological studies have successfully used material from other disciplines to add depth or perception to their research into aspects of childhood, demonstrating the value of this strategy. The present author has woven together evidence from History, Folklore and Art History to explore ways in which medieval

\footnotetext{
${ }^{8}$ Examples chosen entirely at random to illustrate this point are no worse than any others but simply happened to be on my desk when I was writing this paper and include Brown, N. C. 2006. A Medieval Moated enclosure by the Thames Estuary and Thomas. G. 2010. The Later Anglo-Saxon Settlement at Bishopstone: A Downland Manor in the Making. Cessford, C., Alexander, M. and Dickens, A. 2006. Between Broad Street and the Great Ouse: waterfront archaeology in Ely is a rare but honourable exception to this rule.
} 
children's play might appear in the archaeological record (Lewis 2009; see also the introduction to the present volume), while another example is by Stig Welinder, Anna Kjellström and colleagues who found in Folklore an explanation for their discovery of seventeen deciduous (milk) teeth in a fourteenth-century log house at Tibrandsholm in Sweden (Olofsson and Welinder 2004; Kjellström et al. 2011). Excavation showed that the teeth were all found along the southern and western walls of the house (Kjellström et al. 2011, 153-4), suggestive of deliberate, structured deposition. In an attempt to find an explanation, early twentieth-century folklore collections from Norway and Sweden (Kjellström et al. 2011, 155) were examined for beliefs pertaining to lost deciduous teeth. These revealed a number of traditions intended to prevent teeth from falling into malign supernatural hands (which was widely considered likely to harm the child if it happened). One practice involved wedging the shed teeth into the timbers of house walls (Kjellström et al. 2011, 156, citing Tillhagen 1983 and Rooth 1982): this fitted perfectly with the observed locations of the Tidbrandsholm teeth. Although this tradition had been claimed by folklorists as of probable early origin, such claims had lapsed in recent years in line with recent academic scepticism (as discussed in this chapter, pp. 00-00). This scepticism appears to be refuted by this interdisciplinary research at Tidbrandsholm, which has not only identified the possible reasons behind an archaeologically-observed phenomenon, but also demonstrated the likely antiquity of a recently documented folk tradition: the Tidbransholm teeth were certainly deposited by the seventeenth century, and possibly as early as the fourteenth century.

While being excited by the visions that non-archaeological techniques can provide, it should also be recognised, of course, how much archaeology can contribute to broadening and advancing knowledge and understanding of medieval children in its own right. Among other virtues, archaeology is less socially-restricted than most historical evidence, less consciously mediated by artifice than composed works of literature or art, and more dateable than folklore. Archaeological analysis can be conducted at varying scales, exploring entities as large as landscapes or as small as individual cells, time periods as long as millennia or as short as days. Archaeology is, of all the disciplines reviewed here, the only one in which new sources of evidence are still constantly being discovered, and in which we must always be aware that only a tiny percentage of the existing evidence has yet been investigated in detail. Scientific analytical techniques are becoming ever more sophisticated, increasing the information that can be elicited from archaeological material, old or new. Archaeology is capable of providing information about intimate details of individual lived lives which may not even have been known to the individual themselves, which can, furthermore, be aggregated to generate population-level long-term studies. Simon Mays' analyses of the human remains from Wharram Percy (north Yorkshire) (Mays et al. 2007; Mays 2010), which include 312 individuals aged under about sixteen years (45\% of the total) (Mays $2007,89)$, provide just one compelling example of what archaeological investigation can reveal about a rural medieval community for whom no other substantive historical, literary, artistic or folklore evidence survives. While Judith Bennett commented in 1987 that 'the first dozen years of life in the medieval countryside defy historical reconstruction' (Bennett 1987, 68), it is certainly not the case that these years defy archaeological reconstruction, let alone interdisciplinary reconstruction.

The four disciplines reviewed above are all very different, but common themes 
emerge. Post-modernism has impacted on all (Thomas 1994, 12; Scott 1997, 4-5) and the whiff of Keith Thomas' 'death of certainty' is certainly evident, in some more than others, although it has not wreaked the havoc that was once feared. The study of children and childhood is benefiting in all disciplines from the post-modern interest in multiple narratives and under-represented sectors of society. Another welcome consequence of post-modernism is the broadening out of scholarly interests from inward-looking source-centred studies towards a more sociologically-orientated concern with what the source material can reveal about the societies that produced it, even if confidence in the possibility of making useful progress is sometimes low: all disciplines recognise that their evidence is partial and biased. However, scholars in each of the disciplines reviewed above are of the opinion that while the message of their sources is inevitably mediated by cultural transmission, our interest in the meaning behind the mediation (as well as the presented meaning) justifies our use of the source material, although it does inevitably make it more difficult to understand. Ontological and hermeneutic analyses in each discipline have suggested that while cultural transmissions may not represent literal facts, the tropes presented must have been recognisable by contemporary audiences as close to reality in order for them to perform the purposes for which they were created.

As a result of these developments, the aims and principles of History, Art History, Literature, Folklore Studies and Archaeology (and indeed many other social sciences) are closer than ever before, which advances the potential for greater inter-disciplinarity. Indeed, it is apparent from the inter-relatedness of the case studies discussed above that any source, any idea, should be read and explored using whatever techniques and approaches are best suited to advancing knowledge and understanding. Source material, along with spheres of interest, should not occupy a single ascribed disciplinary pigeonhole, but a fuzzily-bounded zone within a multi-dimensional disciplinary spectrum, having aspects which may be susceptible to (and benefit from) analysis or interpretation using different techniques.

\section{Conclusion}

This chapter has aimed to show how analyses from different disciplines can advance knowledge and understanding about medieval children, and inform and support each other. While it is impossible for today's researcher to be the perfect Renaissance scholar, comprehensively knowledgeable across a range of subjects, it is hugely advantageous that those interested in medieval childhood know as much as possible about the potential inherent in other disciplines. We must also, of course, ensure we are aware of the limitations of the evidence we are exploring and the reliability of the scholar who presents it, being aware that we all suffer the problem that ' $[n]$ othing we do ... can be done with certainty' (Schultz 1995, 263). But thus armed, we should be willing and able to proceed, in informed acceptance of the difficulties 'because we think we can learn something we want to know ... if we refuse out of methodological squeamishness to speculate on what it might be able to tell us about the lives of real children, then we will be left knowing almost nothing about them at all' (Schultz 1995, 263).

The range of different sources and analytical techniques available to the study of 
medieval children gives this period great potential strengths, but also presents challenges, as interdisciplinary awareness of the type it requires, and merits, is always difficult. But it also creates opportunities to generate new knowledge and understanding of the experience of childhood and its impact on society which is robust, compelling and nuanced because it is inter-disciplinarily derived. The study of medieval childhood is growing in vigour and confidence in its many separate disciplines, but to fulfil its potential this multi-disciplinary subject should strive for ever greater inter-disciplinary cooperation.

\section{Bibliography}

Ariès, P. 1960. L'enfant et la vie familiale sous l'ancien régime. Paris: Librairie Plon (English translation Baldick, R. 1962. Centuries of Childhood. London: Jonathan Cape).

Aston, M. 2003. The use of images, pp. 69-73 in Marks, R. and Williamson, P. (eds), Gothic: art for England 1400-1547. London: V\&A Publications.

Avery, G. 1995. The beginnings of children's literature to c.1700, pp. 1-25 in Hunt, P. E. (eds), Children's Literature: an illustrated history. Oxford: Oxford University Press.

Badham, S. and Oosterwijk, S. 2012. The monument of Katherine (1253-7), daughter of Henry III and Eleanor of Provence. Antiquaries Journal 92, 169-96.

Baxter, J. E. 2005. The Archaeology of Childhood: children, gender and material culture. Walnut Creek: Altamira Press.

Bennett, J. M. 1989. Women in the Medieval Countryside. Gender and household in Brigstock before the plague. Oxford: Oxford University Press.

Blake, A. 1993. Children and suffering in Shakespeare's plays. The Yearbook of English Studies 23, 293-304.

Brown, N. C. 2006. A Medieval Moated Enclosure by the Thames Estuary: excavations at Southchurch Hall, Southend, Essex (East Anglian Archaeology 115). Norwich: East Anglian Archaeology.

Cannadine, D. (ed.) 2002. What is History Now? London: Macmillan.

Carr, E. H. 1961. What is History? London: Random House.

Cessford, C., Alexander, M. and Dickens, A. 2006. Between Broad Street and the Great Ouse: waterfront archaeology in Ely (East Anglian Archaeology 114). Norwich: East Anglian Archaeology.

Chamberlain, A. T. 1997. Commentary: missing stages of life - towards the perception of children in archaeology, pp. 248-50 in Moore, J. and Scott, E. (eds), Invisible People and Processes: writing gender and children into European Archaeology. London: Leicester University Press.

Chedzoy, K., Greenhalgh, S. and Shaugnessy, R. (eds) 2007. Shakespeare and Childhood. Cambridge: Cambridge University Press.

Comeaux, M. L. 2005. What games can say: two medieval games from French Louisiana. The Journal of the Louisiana Historical Association 46 (1), 47-63.

Crawford, S. and Lewis, C. 2008. Childhood studies and the Society for the Study of Childhood in the Past. Childhood in the Past 1, 5-16.

Crawford, S. and Shepherd, G. (eds) 2007. Children, Childhood and Society (British Archaeological Reports International Series 1696). Oxford: Archaeopress.

Cunningham, H. 2005. Children and Childhood in Western Society since 1500. Harlow: Longman.

Darwin, C. 
deMause, L. (ed.) 1974. The History of Childhood. New York: Psychohistory Press.

Eagleton, T. 1996. Literary Theory: an introduction (second edition). Oxford: Blackwell.

Elton, G. 1967

Forsyth, H. and Egan, G. 2005. Toys, Trifles and Trinkets: base-metal miniatures from London 11501800. London: Unicorn Press.

Gavin, A. E. (ed.) 2012a. The Child in British Literature: literary constructions of childhood, medieval to contemporary. London: Palgrave Macmillan.

Gavin, A. E. 2012b. The child in British literature, pp. 1-19 in Gavin, A. E. (ed.), The Child in British Literature: literary constructions of childhood, medieval to contemporary. London: Palgrave Macmillan.

Gilchrist, R. 2012. Medieval Life: archaeology and the life course. Woodbridge: Boydell.

Giles, J. A. (ed.) 1847. William of Malmesbury's Chronicle of the Kings of England. London: Henry G. Bohn.

Goldberg, J. P. J. 1992. Women, Work and Life Cycle in a Medieval Economy. Women in York and Yorkshire, c. 1350-1520. Oxford: Oxford University Press.

Gombrich, E. H. 1950. The Story of Art. London: Phaidon.

Gomme, A. 1894. The Traditional Games of England, Scotland and Ireland Volume 1. London: D. Nutt.

Gomme, A. 1898. The Traditional Games of England, Scotland and Ireland Volume 2. London: D. Nutt.

Hanawalt, B. 1986. The Ties That Bound. Peasant families in medieval England. Oxford and New York: Oxford University Press.

Hanawalt, B. 1993. Growing Up in Medieval London: the experience of childhood in history. Oxford: Oxford University Press.

Heywood, C. 2001. A History of Childhood. Oxford: Blackwell.

Hills, J. 1957. Das Kinderspielbild von Pieter Bruegel d. A., 1560: eine volkskundliche Untersuchung. Vienna: Osterreichischen Museums für Volkskunde.

Hindman, S. 1981. Pieter Bruegel's Children's Games, folly, and chance. The Art Bulletin 63 (3), $447-75$.

Jenks, C. 1996. Childhood. London: Routledge.

King, M. L. 2007. Concepts of childhood: what we know and where we might go. Renaissance Quarterly 60 (2), 371-407.

Kjellström, A., Olfsson, C., Stenbäck Lönnquist, U. and Welinder, S. 2011. Living children, pp. 152-61 in Lally, M. and Moore, A. (eds), (Re)Thinking the Little Ancestor: new perspectives on the archaeology of infancy and childhood (British Archaeological Reports International Series 2271). Oxford: Archaeopress.

Kline, D. T. 2005. Medieval Literature for Children. London: Routledge.

Kline, D. T. 2012. 'The child may doon to fadres reverence': children and childhood in Middle English literature, pp. 21-37 in Gavin, A. E. (ed.), The Child in British Literature: literary constructions of childhood, medieval to contemporary. London: Palgrave Macmillan.

Knowles, K. 2012. Shakespeare's 'terrible infants'? Children in Richard III, King John and Macbeth, pp. 00-00 in Gavin, A. E. (ed.), The Child in British Literature: literary constructions of childhood, medieval to contemporary. London: Palgrave Macmillan.

Labarge, M. W. 1986. Women in Medieval Life. London: Penguin.

Lewis, C. 2009. Children's play in the later medieval English countryside. Childhood in the Past 2, 86-108. 
Leyser, H. 1995. Medieval Women. London: Weidenfeld and Nicholson.

Lillehammer, G. 1989. A child is born. The child's world in archaeological perspective. Norwegian Archaeological Review 22 (2), 91-105.

Lillehammer, G. (ed.) 2010. Socialization. Recent research on childhood and children in the past. Stavanger: Stavanger Museum.

Lyell, C.

MacFarlane, A. 1985. Marriage and Love in England: modes of reproduction, 1300-1840. Oxford: Blackwell.

MacLehose, W. 2006. A Tender Age: cultural anxieties over the child in the twelfth and thirteenth centuries. New York: Columbia University Press.

McCormick, C. T. and White, K. K. 2011. Folklore: an encylopedia of beliefs, customs, tales, music and art. Santa Barbara: ABC-CLIO.

McDowell, J. 1995. The transmissions of children's folklore, pp. 49-62 in Sutton-Smith, B., Mechling, J., Johnson, T. W. and McMahon, F. R. (eds), Children's Folklore: a sourcebook. New York: Garland Press.

McMahon, F. and Sutton-Smith, B. 1995. The past in the present: theoretical directions for children's folklore, pp. 293-308 in Sutton-Smith, B., Mechling, J., Johnson, T. W. and McMahon, F. R. (eds), Children's Folklore: a sourcebook. New York: Garland Press.

Mays, S. 2012. The effects of infant feeding practices on infant and maternal health in a medieval community. Childhood in the Past 4, 63-78.

Mays, S., Harding, C. and Heighway, C. (eds) 2007. The Churchyard. Wharram. A study of settlement on the Yorkshire Wolds. Volume XI. York: York University Publications.

Miller, H. (ed.) 1995. The Hours of Mary of Burgundy (facsimile edition with a commentary by E. Inglis). London: Harvey Miller Publishers.

Olofsson, C. and Welinder, S. 2004. Historiens avfall, pp. 7-21 in Kjellson, C., Olofsson, S. and Sörlin, P. (eds), Blickar bakåt. Elva uppsatser om ett förgånget nu. Härnösand: Mitthögskolan, Institutionen för humaniora.

Oosterwijk, S. 2008. The medieval child: an unknown phenomenon?, pp. 230-5 in Harris, S. J. and Grigsby, B. (eds), Misconceptions about the Middle Ages. New York and London: Routledge (also available at http://www.the-orb.net/non_spec/missteps/ch6.html).

Oosterwijk, S. 2010. Deceptive appearances: the presentation of children on medieval tombs. Ecclesiology Today 43, 45-60.

Opie, I. and Opie, P. 1959. The Lore and Language of Schoolchildren. Oxford: Oxford University Press.

Opie, I. and Opie, P. 1969. Children's Games in Street and Playground. Oxford: Oxford University Press.

Orme, N. 1973. English Schools in the Middle Ages. London: Methuen.

Orme, N. 1989. Education and Society in Medieval and Renaissance England. London: Hambledon Press.

Phillips, K. M. 2008. Review of William F. MacLehose, A Tender Age: cultural anxieties over the child in the twelfth and thirteenth centuries. American Historical Review 113 (4), 1216-17.

Pooke, G. and Whitham, G. 2010. Understand Art History (second edition). London: Hodder Education.

Porter, R. 1997. The Greatest Benefit to Mankind. A medical history of humanity from Antiquity to the present. London: Harper Collins.

Postman, N. 1995. The Disappearance of Childhood. London: Vintage Books. 
Rawcliffe, C. 1995. Medicine and Society in Later Medieval England. Sutton: Stroud.

Rooth, A. B. 1982. The 'offering' of the first shed tooth and the tooth-formula: A study of a physiological custom. Uppsala: Etnologiska institutionens Småskriftserie 30.

Rosenthal, J. T. 2007. Essays on Medieval Childhood: responses to recent debates. Donnington: Shaun Tyas.

Rutter, C. C. 2007. Shakespeare and Child's Play: performing lost boys on stage and screen. Abingdon: Routledge.

Schultz, J. 1995. The Knowledge of Childhood in the German Middle Ages 1100-1350. Philadelphia: University of Pennsylvania Press.

Scott, E. 1997. Introduction, pp. 1-12 in Scott, E. and Moore, J. (eds), Invisible People and Processes: writing gender and childhood into European prehistory. London: Leicester University Press.

Shahar, S. 1990. Childhood in the Middle Ages. London: Routledge.

Simpson, J. and Roud, S. 2000. A Dictionary of English Folklore. Oxford: Oxford University Press

Stanbury, S. (ed. and trans.) 2001. Pearl. Western Michigan University: Medieval Institute Publications.

Stanbury, S. 2009. The Gawain poet, pp. 139-51 in Scanlon, L. (ed.), The Cambridge Companion to Medieval English Literature 1100-1500. Cambridge: Cambridge University Press.

Stone, L. 1977. Family, Sex and Marriage in England 1500-1800. London: Weidenfeld and Nicholson.

Sutton-Smith, B. 1970. Psychology of childlore: the triviality barrier. Western Folklore 29, 1-8.

Sutton-Smith, B. 1995. Introduction: what is children's folklore?, pp. 3-10 in Sutton-Smith, B., Mechling, J., Johnson, T. W. and McMahon, F. R. (eds), Children's Folklore: a sourcebook. New York: Garland Press.

Sutton-Smith, B., Mechling, J., Johnson, T. W. and McMahon, F. R. (eds) 1995. Children's Folklore: a sourcebook. New York: Garland Press.

Terrell, K. T. 2008. Rethinking the 'Corse in Clot': cleanness, filth, and bodily decay in 'Pearl'. Studies in Philology 105 (4), 429-47.

Tillhagen, C.-H. 1983. Barnet i folktron. Tillblivelse,födelse och fostran. Stockholm: LTs förlag.

Thomas, K. 1994. The death of certainty. The Guardian 6th September, 12.

Tolstoy, L. 1995. What is Art? (translated from 1896 Russian edition by R. Pevear and L. Volokhonsky). London: Penguin.

Webb, D. 1984. Introduction, pp. 5-15 in Gomme, A. The Traditional Games of England, Scotland, and Ireland (reprint of 1894 and 1898 editions). London: Thames and Hudson.

Wileman, J. 2005. Hide and Seek: the archaeology of childhood. Stroud: Tempus. 